\title{
The effect of government involvement and payment method on merger and acquisition performance: the case of China
}

\author{
Matthias Nnadi ${ }^{1}$ \\ Cranfield University, UK \\ Evgeniia Volokitina \\ National College of Ireland, Ireland \\ Daniel Aghanya \\ Cranfield University, UK
}

\begin{abstract}
This paper applies a sample of 842 to investigate the effect of government involvement and payment methods on merger and acquisition of Chinese listed firms for the period 1993 - 2015. The study employs market model as benchmark to estimate expected returns for several event windows. We find that Chinese acquirer shareholders experience higher returns from the acquisitions in firms with no government involvements than those where government is involved. Our study demonstrates that stock-financed acquisitions maximise the wealth gains of shareholders than cash-backed acquisitions. Our finding further shows that using cash to finance government backed acquisitions yields extra wealth for investors on the announcement date whilst the market experience higher abnormal returns when stocks are used to finance the acquisition of privately held targets. The result of this paper has significant policy implications for both M\&A financing decisions and government involvements in merger deals.
\end{abstract}

Keywords: mergers; performance; acquisition; Chinese, returns, government

Acknowledgement: We wish to thank the anonymous reviewers and the editor for their comments and the participants at the 2016 ICAFFI, Poznan Poland for some helpful feedback on the earlier version of the manuscript.

\footnotetext{
${ }^{1}$ Corresponding email: Matthias.nnadi@cranfield.ac.uk
} 


\section{Introduction}

A handful of studies agree that mergers and acquisitions (M\&As) have become an increasingly popular channel to boost profitability, increase market power, improve performance, and a major strategy for firm growth (e.g., Mantecon, 2008; Wan and Yiu, 2009). Beyond national boundaries, many firms also utilise M\&As as an internationalisation strategy to build foreign presence (King et al., 2004). According to Thomson Reuters' 2017 M\&As review, global M\&As activity was about 3.6 trillion US dollars in 2017. This represents 50\% increase from 2.4 trillion US dollars announced deals in 2010 (Thompson Reuters, 2010).

Surprisingly, despite the staggering popularity of M\&As as an essential means of firm expansion and control of resources [e.g., Harrison et al., (2001) and Savor and Lu (2009)], there is dearth in empirical evidence on the role of government support in mergers and acquisition, most especially in emerging economies such as Russia, China, India and Brazil were state-owned enterprises (SOEs) are still an important feature of the modern day economies (Del Bo et al., 2017). Government involvement may provide acquirers with access to strategic resources such as cheaper source of finance (Guariglia et al., 2011), and enables the SOEs to be able to bear short-term losses and offers them ample resources to overcome risks and uncertainties. ${ }^{2}$ For example, whilst the majority of Chinese banks are government owned, their main function is to provide support for SOEs' economic activities (Morck et al., 2008), limiting private firms (non-SOEs) competitive financing and liquidity opportunities. Not surprising that Zhou et al. (2015) document that SOE acquirers outperform non-SOEs acquirers. Therefore, government involvement in acquisition may influence bidding firm positive abnormal returns. On the contrary, government support can be counterproductive, leading to value-losing acquisitions (Black et al., 2015). Chen and Young (2010) document investor negative reaction to cross-border M\&As of Chinese firms with government involvement. Given these contrasting standpoints, the first goal of the study is to provide further insight to the literature on M\&As by answering the question: does government (non) involvement in acquirer's merger activities impact on short-term performance?

In related literature, the choice of payment method (such as cash, stock, or mixed) is an important issue in the M\&A process. A significant body of literature provides mix evidence of

\footnotetext{
${ }^{2}$ In this study, government involvement includes both domestic and cross-border mergers and acquisitions.
} 
the impact of choice of payment on firm performance (Fuller et al., 2002; Faccio and Masulis, 2005; Cho and Ahn, 2017). Savor and Lu (2009), for example, find evidence that equityfinanced deals generate significantly negative average returns to acquirers compared to cashfinanced deals. In contrast, Dutta et al. (2013) document a positive impact of using stock as method of payment in cross-border M\&A deals. ${ }^{3}$ Given these inconsistent views of the influence of payment methods in the M\&A process, which has also been overlooked in empirical studies of emerging market (Fischer, 2017), the next goal of the study is to answer the question: does mode of payment create wealth for bidding shareholders with government (non) involvement in the short-term?

Moreover, the choice of target firm (public or private) also influences acquirer's performance (Draper and Paudyal, 2006). Mantecon (2008) documents that acquirers benefit from the acquisition of privately held firms but do not gain in the purchase of publicly traded firms. Though some studies on M\&A have extensively analysed the acquirer's performance in relation to publicly held targets, research of their performance relating to privately held targets firms remain largely unexplored (e.g., Shen, 2006); and majority of acquisitions involve private firms (Erel et al., 2012). Furthermore, examining the post-acquisition performance of bidding firms based only on publicly traded firms' raise an econometric concern that the ordinary least square regression might suffer from sample selection bias (e.g., Heckman, 1979). Given this viewpoint, the third goal of this study is to examine whether payment method creates wealth for acquiring shareholders with privately held or publicly held targets in the short-run?

Indeed, the M\&A deals are prevalent not only in the developed markets but also in the emerging markets. However, as noted in Dutta and Jog (2009), many of these studies suffer from data mining biases because they exhibit a heavy focus on the well-established markets such as the United States (US) and United Kingdom (UK). The existing literature on M\&A has paid little attention on emerging countries (e.g., Erel et al., 2012; Thanos and Papadakis, 2012) and thus limits the generalisability of the findings. The focus on well-established markets may be due to better accounting reporting standards that ensures high quality of data (e.g., Chui and Kwok, 1998). While several studies on merger activities focus on publicly held firms in the US, the

\footnotetext{
${ }^{3}$ The terms mergers, acquisitions, mergers and acquisitions, takeovers, deals and transactions are used interchangeably in this paper.
} 
greater number of international acquisitions is private and does not involve the US firms (Erel et al., 2012). Moreover, the worldwide growth in international takeovers (Thompson Reuters, 2017) and the new globalisation trend that involves cross-border merger activities (Lebedev et al., 2015) has significant implications relating to the emerging economies. Our study therefore provides novel evidence and advances our understanding of the effects of mergers and acquisitions on short-term post-acquisition performance related to emerging markets.

Despite reforming for many years, Chinese government still plays crucial role in business activities; and corporate investment and financing decisions are significantly influenced by government intervention (Firth et al., 2008). As a direct means of resource reallocation and ownership transfer, M\&As might therefore be influenced by the government to achieve political and economic goals. For instance, acquirers with the government involvement might have comparative advantage and enjoy strict control of ownerships and hence, take advantage of access to special loans in line with government priorities, such as low interest loans from government-owned banks in M\&A deals. Thus, the above characteristics make the Chinese market an ideal setting to examine the impact of M\&As on the bidder's performance.

Though China has a large population and second largest investing country globally (Fan et al., 2011 and UNCTAD, 2017), their capital market remains underdeveloped (Lin and Ye, 2018). This has been associated with poor information asymmetry (Piotroski and Wong, 2012) which allows government to facilitate acquisitions especially for SOEs. Moreover, China has been the fastest growing economy in recent decades with completed worldwide acquisition trading volume of 2655, and with transaction value of approximately $\$ 300$ billion at end of 2017 (Thompson Reuters, 2017). ${ }^{4}$ However, most of the deals are conducted by Chinese state-owned enterprise (SOE) and existing evidence about the Chinese M\&A activities is fairly limited (Ahlstrom et al., 2014; Lebedev et al., 2015). Thus, the study contributes to the sparse literature on the association between the roles of (Chinese) government policy and acquirer's postacquisition performance. Thus, our empirical analysis of China has significant implications for emerging economies with large population and geographic size but with underdeveloped capital markets.

\footnotetext{
${ }^{4}$ https://www.thomsonreuters.co.jp/content/dam/openweb/documents/pdf/japan/market-review/2017/ma-4q2017-e.pdf.
} 
Our study makes important contribution to existing M\&As literature by providing a comprehensive evidence of the effects of merger activities on Chinese acquirer's short-term performance. First, our result shows that unlike most advanced economies were bidder shareholders experience negative abnormal returns from acquisition (Fuller et al., 2002 and Nnadi and Aghanya, 2018), Chinese acquirer shareholders experience positive abnormal return from the acquisition. Second, we also extend to the literature on the choice of payment in M\&A transactions. We show that contrary to substantial empirical evidence that cash-financed acquisitions is preferred ( Draper and Paudyal, 2006, Fu et al., 2013, and Black et al., 2015), our study shows that in the Chinese context, shareholders perceive that stock-financed acquisition maximise the wealth gains. Third, our study also conducts a comprehensive analysis of the effect of government involvement in acquisition in relation to the payment methods. Our results show that in the case of Chinese acquisitions, the mean difference is negative and statistically significant on the announcement date, suggesting SOEs have higher corporate liquidity (or cheaper source of finance) that favours cash-financed acquisitions. Finally, our study also conducts a comprehensive analysis of bidder's choice of target firms in relation to the different payment methods. Our findings show that the market experience more positive abnormal return using stock as financing decision for the acquisition of privately held targets.

The rest of the paper is structured as follows: Section 2 is the theoretical background, literature and hypothesis. Section 3 describes the data used in the study and research methodology. Section 4 is the empirical results and discussion of findings while Section 5 is the conclusion.

\section{Theoretical background, Literature review and hypothesis development}

the choice of payment can have a substantial effect on corporate control, taxation, risk bearing, financial leverage, cash flow implications, and ownership structure of the bidding and target firms, and as well as on shareholders. Several studies document that M\&A financing decision: a choice of stock, cash only or a combination of cash and stock can influence share price performance (e.g., Faccio and Masulis, 2005; and Harford et al. 2009).

Our study is based on the asymmetric information theory argues that unequal information exists between inside managements and outside investors. Therefore management will exploit the 
market condition and offer stock exchange when the bidding firm stock is overvalued by the market but offer cash on the opposite condition (e.g., see Myers and Majluf, 1984). Interestingly, investors who do not have superior information as managers do, will take a stockfinanced acquisition as a signal for mispricing (Burkart and Lee, 2016), and treat the deal as bad news (Myers and Majluf, 1984; Travlos, 1987), suggesting that the market react more favourably to cash-financed takeover transactions compared to stock-financed takeovers. This can be explained as firms tend to hold cash against expected shortfall to prevent them from underinvesting. Extending this argument to the Chinese market, Yang et al. (2017) posit that acquirers with financial constraints would rather pay with stock than cash on acquisitions. Alternatively, tax-based hypothesis posit that target shareholders may prefer to defer capital gains taxation by opting for share payment, this will postpone taxes until the stock is sold (see Fuller et al., 2002).

Another important factor in corporate acquisition is the acquirer's choice to buy either a public target firm or a private target firm (Bena and Li, 2014). Empirical literature has emphasised the impact on shareholder expectations of bidding firm following the choice of target firms. Fuller et al., (2002) explore reasons why the acquisition of private targets elicit favourable shareholders' reaction in relation to publicly-held targets A growing body of literature presents three hypotheses (not mutually exclusive) that underpin shareholders preference for acquiring private firms in comparison to public firms. The first hypothesis (private firm discount) provides an alluring upside for bidding for non-listed firms. The hypothesis posits that private firms have lower quality or no observable financial information that impedes the preacquisition evaluation process. Moreover, because private firms are more informationally opaque to the public, they are considered riskier than publicly held firms, inducing uncertainty about their future prospects. As a result, private firms are significantly less liquid, leading them to be acquired at a discount. In line with this view, John et al. (2010) find that the returns to acquirers of privately held targets are generally more favourable than publicly held targets. The second hypothesis (principal-agent) posits that firm's management may seek to bid for private firms to either maximise shareholders' wealth or enhance their private benefits tied up in the firm. ${ }^{5}$ Hence, the market may react more positively to takeover of privately held firms relative 
to public firms. The third hypothesis (information asymmetry) posits that because the many privately held firms are usually small with higher information asymmetry and according to Capron and Shen (2007), they might have weaker bargaining power because of (1) their illiquidity position, (2) lower interest from potential bidders, and (3) lower publicity and visibility on the acquisition process of privately held firms. Notwithstanding the arguments, Wulf (2004), provides evidence that greater bargaining power does not essentially generate positive gains for investors.

\subsection{Acquirer's short and long-terms performances and payment methods}

Some studies have concluded that target firms outperform significantly both around the announcement day and in the long-term, but the acquirer's performance over the same period is not conclusive (Jensen and Ruback, 1983). For example, Bruner (2004) conducts an overview of 50 studies focusing on short term performance of acquirers in merger and acquisition transactions. He finds that almost half of the researchers observed significant positive returns (Leeth and Borg, 2000), and one third of the papers including Smith and Kim (1994) and Eckbo and Thorburn (2000) state that abnormal returns were not significantly different from zero. However, Walker (2000) reports negative abnormal returns around the announcement periods.

The findings of performance for bidders over long period after transaction are even more inconclusive than short-term results. According to Bruner (2004), about 60 percent of M\&As studies report significant negative abnormal returns. For example, Agrawal, Jaffe and Mandelker (1992) and Gregory (1997) report abnormal returns of approximately 10\% lower than zero and a range of $-18 \%$ to $-12 \%$ negative. These findings of negative returns of bidding firm support previous studies that only target shareholders benefit from merger and acquisitions. Some earlier studies have identified that long term performance examinations are dependent on benchmark issues (Rau and Vermaelen, 1998; and Sudarsanam and Mahate, 2003).

In regard to cross-border and domestic M\&As, most of the extent literature document that cross-border takeovers create lower value compared to domestic acquisitions. For example, Moeller and Schlingemann (2005) established same finding in the U.S; Conn et al (2005) and 
Aw and Chatterjee (2004) in the U.K; Campa and Hernando (2004) and Goergen and Renneboog (2004) for Continental European, Eckbo and Thorburn (2000) for Canadan, and Lowinski et al. (2004) for Swiss markets. However, the results in emerging markets are different as studies show that bidders undertaking international M\&A deals gained more returns compared to domestic ones (Rani et al., 2011; Barai and Mohanty, 2010; Gubbi et al, 2010; Karels et al., 2011; and Zhu and Malhotra, 2008). However, few studies have focused on Chinese market, and many of them are limited to small sample sizes.

Several studies have demonstrated that globally, cash offers can create more return to bidding firm shareholders than stock offers (Baker et al, 2012). This is because most foreign targets are unwilling to accept foreign companies' shares, thus balancing off the positive effect of cash offer (Gaughan, 2002; Ye and Yuan, 2014). Boateng and Bi (2013) compared the preannouncement and post announcement returns with pure cash or stock payment in China M\&As, and found that Chinese bidders report pre-deal abnormal returns varying from $14.29 \%$ to $121 \%$ over the period of 1 to 3 years prior to the announcement. However in the post-bid period, no significant difference between cash-financed and stock financed was found.

\section{$2.2 \quad$ Hypotheses development}

Extant literature suggests that payment methods used for takeover activities can influence acquirer's stock returns (Faccio and Masulis, 2005). According to Martin (1996), M\&A financing decisions can be classified into stock and cash. Cash payment method can generate higher positive abnormal returns than stock payments. An explanation for the phenomenon is that a rational investor knows that bidding management is better motivated to pay in cash when synergies are higher, hence paying with stock signals a lower level of synergy gains in the merger activities. For instance, The M\&A deals financed with cash significantly outperform those financed by shares (Loughran and Vijh, 1997). Faccio and Masulis (2005) report that bidders choose cash financing to protect their voting power. Their study examined the bidders' financing choice of M\&A deals from 13 European countries over the period from 1997 to 2000, and find evidence that bidders are more likely to use cash-only financing if they are purchasing privately held targets. Similarly, Draper and Paudyal (2006) show that stock financing conveys 'bad' news, whilst paying with cash generates significant positive abnormal returns for the acquirer shareholders. Additionally, $\mathrm{Fu}$ et al. (2013) find evidence that stock-financed 
acquisitions (overvalued acquirers) increase target's stock price and lower acquirer's stock price. In regard to cross-border and domestic M\&As, existing literature find that globally, cash offers create more return to bidding firm shareholders than stock offers (Black et al., 2015).

On the contrary, research suggests that stock financing can generate higher positive abnormal returns for acquirer shareholders. For example, Dutta et al. (2013) examine the effect of financing decisions by Canadian bidders between 1993 and 2002 and find a significant positive abnormal return for stock-financed cross-border acquisitions. Similarly, Yang et al. (2017) indicate that bidders' with higher growth opportunities prefer stock-financed acquisitions. Furthermore, Cho and Ahn (2017) document that despite the fact that M\&As stock financing deals have a significant adverse effects on bidder shareholder value, it can be beneficial in takeovers with greater scope of information asymmetry and agency problems. In a related literature, Alexandridis et al. (2010) document that stock-financed acquisitions are generally not value destroying. This collaborate Eckbo et al. (2018), that bidders concerned with adverse selection problems prefer to use stock financing than cash financing. The contrasting evidence surmises that the effects of payment methods on acquisition performance are not obvious and hence we hypothesise in the alternate form:

Hypothesis 1: In the Chinese context, paying with cash or stock will have no effect on acquirer's performance.

We next consider the effect of government and non-government involvement on acquirer merger activities and firm performance. It remains unsettled whether firms can benefit from government involvement in M\&As activities in the Chinese market. According to Deng (2004, p.14), 'Chinese government has, to a great extent, played a crucial role in shaping the structure of the country's approved outward investment'. Calomiris et al. (2010) find that state-owned firms are normally less efficient than private companies. Nevertheless, few studies have shed light on the relationship between government connection and Chinese merger and acquisition activities. Of the limited studies, Wang et al. (2012) suggest that bidders with strong government connection are dominant in the bidding competition against private firms. This is because Chinese government plays a decisive role in the economy and business activities, and bidding against them might incur unsettling results. For some industries that are held as crucial to national defence such as the oil and military sector, only the bidders that are approved by government can take part in the bidding process. In addition, government connection can supply excessive financial support for merger and acquisition (Frye and Shleifer, 1997). 
Therefore, our second hypothesis is in the null form as:

Hypothesis 2a: Shareholders of bidding firms with government influence in takeover activities will not gain more abnormal returns than shareholders of bidding firms without government influence.

Hypothesis 2b: Shareholders of bidding firms with government involvement in takeover activities will not gain more abnormal returns whether paying with cash or stocks.

Hypothesis 2c: Shareholders of bidding firm without government involvement in takeover activities will not gain more abnormal returns whether paying with cash or stocks.

Next, we consider the effect of acquiring private or public targets on short-run firms' performance. A growing body of research documents negative abnormal returns to acquisitions of publicly targeted firms (Ang and Kohers, 2001, and Fuller et al., 2002). The excess return for acquirers can be seen as a compensation for bearing the liquidity risk which refers to the difficulty in converting target stocks or assets into cash at full price. Private firms are therefore less attractive targets than public firms and hence less valuable than listed firms (Fuller et al., 2002). In addition, as the liquidity risk of private targets exists, the illiquidity asset is less likely to be targeted by acquirers, which limits the bidding competition. As a result, an acquirer will not have to pay a higher premium. Therefore, the post-performance of the bidder acquiring private target should be better than those acquiring listed targets (Ang and Kohers, 2001). For example, Faccio et al. (2006) provide evidence that bidders acquiring privately held firms earn favourable abnormal returns than public acquirers. Similarly, Mantecon (2008) shows that bidders benefit from the acquisition of private firms but not so in the purchase of public firms. In the same vein, John et al. (2010) show that the abnormal returns to bidders of private targets are more favourable than publicly targets.

Despite the fact that literature on the acquisitions of public firms has been well documented, studies on returns to acquisitions of private firms relating to emerging economies is scanty (Erel et al., 2012). Given that the findings on the developed markets cannot be generalised because of the substantial differences in M\&As activities between the developed and lessdeveloped markets (Zhou et al, 2016), we argue that the impact on emerging markets are subject to empirical validation. Consequently, this leads to our third null hypothesis:

Hypothesis 3a: Bidder acquiring private firms will not outperform those acquiring public firms. 
Hypothesis 3b: Bidder acquiring public firms will not gain abnormal return paying with cash or stock

Hypothesis 3c: Bidder acquiring private firms will not gain abnormal return paying with cash or stock

\section{Data and methodology}

\subsection{Sample and data collection}

This study investigates the impact of M\&As deals on firm performance of all takeovers bids involving Chinese acquirers between 1993 and 2015. This period is chosen as it was the time of enormous economic growth in China. We obtain our dataset on M\&As deals from the Securities Data Company (SDC) Platinum Mergers and Acquisitions database provided by Thomson Financial and apply the following selection criteria: (i) all acquirers must be Chinese firms and listed in either of the two Chinese stock exchange markets Shanghai (SHCOMP) and Shenzhen (SZCOMP ) composite index (ii) the acquirers do not hold more than $50 \%$ of the target firms before the bid and will hold more than $50 \%$ of the target firms afterwards, which means that only acquiring equity is considered, (iii) the acquirers must not have announced other capital actions such as announcement of dividends, seasonal offering of new shares, and announcement of new investment that might have effect on the share prices within 30 days prior and after the takeover, (iv) in order to test the announcement effect of the takeover event, it is essential to exclude the acquirers that have multiple takeovers, and this significantly reduces the sample size, (v) we require all acquirers to have been trading for at least 100 days during the pre-event period of 250 trading days window to have enough observations to estimate the benchmark, and (vi) all acquirers should have daily prices data available on DataStream. We require bidders to have share price data in DataStream. These criteria lead to our final sample of 842 cases of Chinese M\&As deals, comprising 112 government involved acquisitions and 730 non-government involved takeovers.

Table 1a summarises the information of deals of each category in each year. The study runs from 1993 to 2015 and with more than $50 \%$ of deals occurring in years 2013 to 2015. The majority of the acquisitions are private firms. While 789 firms are privately target firms, only 53 acquisitions are publicly targeted firms. Table $1 \mathrm{~b}$ indicates the sample distribution in terms 
of the industry composition, as reported by DataStream. ${ }^{6}$ There are large differences across industries in the composition of acquirers. We observe the industrial sector constitutes high acquisitive industry with about 33.8 percent of Chinese acquirers followed by the consumer goods industry with 17.8 percent acquirers. Obviously, the table shows our sample is underrepresented in non-industrial sectors. Table 1c shows distribution by type of acquisition and government involvement.

\section{[Insert Table 1 here]}

\subsection{Methodology}

In this paper, we follow standard event study methodology discussed in Brown and Warner (1985) to analyse the short-term performance of acquiring firms. This approach is consistent with previous M\&A research (Aybar and Ficici, 2009, Tao et al., 2017 and Nnadi and Aghanya, 2018) in assessing market's reaction at the acquisition announcement. The underlying assumption of event study methodology is that stock price instantaneously reflects all relevant information (Grossman and Stiglitz, 1980). In addition, Schwert (1981) points out that the price of a firm's stock represents unbiased net present values of its future cash flows as price changes to account for investor's current and future expectations about firm performance associated with the announcement. Hence, the method assesses market efficiency reflected in the abnormal return surrounding the corporate events. Accordingly, we can attribute the abnormal return, without any other jointly announcement event, to the effect of announcement of merger and acquisition. The method is less susceptible to omitted variable problem because of the short time intervals. We identify the actual announcement date as event Day-0 for our event study because it was the day the firm declared the merger activity, and investors could instantly react to new informational content (Fama, 1970). Thus, to gauge market responses to the acquisition announcement, we estimate the abnormal returns (AR) over an event window using the market model defined as:

$$
\mathrm{AR}_{\mathrm{it}}=\alpha_{\mathrm{it}} \mp \beta_{\mathrm{i}} \mathrm{R}_{\mathrm{mt}}+\mathrm{e}_{\mathrm{it}}
$$

\footnotetext{
${ }^{6}$ We use DataStream Industrial Classification Benchmark (ICB) indices (level 1).
} 
where $\mathrm{AR}_{\mathrm{it}}$ is the abnormal return of company $i$ at day $t, R_{i t}$ is the return for firm $i$ at day $\mathrm{t}$, $R_{m t}$ is the return of the market at day $t$, alpha $(\alpha)$ and beta $(\beta)$ for each bidding firm is obtained by regressing the returns of the company on the returns of the market over the estimation window of 250 trading days ending 30 days prior to event day $0 .{ }^{7}$ To examine the wealth effects of M\&As, we calculate the cumulative abnormal return (CAR), which is a measure of market reaction to news over the event window $\left(T_{1}, T_{2}\right)$. We employ the market model by summing the abnormal returns over the event window for each stock as follows:

$\operatorname{CAR}\left(T_{1}, T_{2}\right)=\sum_{T_{1}}^{T_{2}} A R_{i t}$

and for a sample of $\mathrm{N}$ transactions, the cross-sectional cumulative average abnormal return is given as follows:

$\operatorname{CAAR}\left(T_{1}, T_{2}\right)=\frac{1}{N} \sum_{i=1}^{N} \sum_{T_{1}}^{T_{2}} A R_{i t}$

where CAAR denotes cumulative average abnormal returns, $\mathrm{N}$ is the number of companies, $T_{1}$ is the beginning of the event window and $T_{2}$ is the end of the event window. To further investigate whether fluctuation in stock prices influence the CAAR, we test the statistical significance using the cross-sectional data, the test-statistic is calculated by the following formula:

$T_{\text {cross }}=\frac{\operatorname{CAAR}\left(T_{1}, T_{2}\right)}{\widehat{\sigma}_{\operatorname{CAAR}\left(T_{1}, T_{2}\right)}}$

where, $T_{\text {cross }}$ is the test-statistic of the cumulative average abnormal returns,

$\hat{\sigma}^{2} \operatorname{CAAR}\left(T_{1}, T_{2}\right)=\frac{1}{N(N-d)} \sum_{i=1}^{N}\left[C A R\left(T_{1}, T_{2}\right)-\operatorname{CAAR}\left(T_{1}, T_{2}\right)\right]^{2}$

in which $d$ is the degree of freedom and $\hat{\sigma}^{2}{ }_{C A A R}\left(T_{1}, T_{2}\right)$ is the variance of each firm during the event period.

Following Boehmer et al. (1991) and Corrado and Truong (2008), we apply both parametric and non-parametric test statistics to address any skewness bias. Each of the statistics tests the null hypothesis that population abnormal returns are zero; but the assumptions of the statistical characteristics of the abnormal return are different. The parametric test indirectly assumes that the residuals follow normal distribution, whereas the non-parametric test does not demand strict

${ }^{7}$ The 250 trading days corresponds to about one year of trading (see Acemoglu et al., 2016) 
assumptions about return distribution and are generally used together with parametric test to confirm that the outcomes are not driven by outliers. Regarding parametric test, Boehmer test is applied, while we apply the Corrado's rank test statistic with regards to the non-parametric test (Boehmer et al., 1991 and Corrado 1989).

Boehmer et al, (1991) show that if the variance of stock returns increases around the event date, the standardised residuals test rejects the null hypothesis too often. They combine the standardised residuals test with an empirical variance estimate, based on the cross section of event-window abnormal returns, to construct a test that is robust to event-induced variance of stock returns. Corrado (1989) proposes a non-parametric rank test by transforming all abnormal returns into ranks for every asset in each estimation period. We present all tests as discussed above to make more reliable statistic inference.

Since extant literature does not have a laid down criteria for the suitable length of the event window, and as more observations can contribute to the credibility of parameter estimation in regression, we follow (Aybar and Ficici, 2009 and Tao et al., 2017) and consider a short event window because a longer window can reduce the chance in observing any reliable evidence. As a result, we use a 1-day (0), 3-day $(-1,+1), 5$-day $(-2,+2), 7$-day $(-3,+3)$, and 11-day $(-5$, +5 ) event window around the announcement date to investigate investors' short-term reaction to the merger declaration. ${ }^{8}$

In addition to using market returns to estimate CAR (Brown and Warner, 1985), we also use market adjusted return as our second approach to establish the robustness of our results. The method involves no estimation but rather market-adjusts raw returns in order to attenuate confounding news caused by potentially overlapping and concurrent observations that could have an impact on stock prices. Thus, market adjusted abnormal return $\left(\mathrm{AR}_{\mathrm{it}}\right)$ is calculated as the difference between the actual stock return $\left(\mathrm{R}_{\mathrm{it}}\right)$ and the market return $\left(\mathrm{R}_{\mathrm{mt}}\right)$. Table 2 provides descriptive statistics of the market reaction to M\&A announcements for the bidding firms.

\section{[Insert Table 2 here]}

\footnotetext{
${ }^{8}$ We choose the maximum of eleven-day period $(-5,+5)$, that is, five trading days pre- and post-merger announcement because Kiesel et al. (2017) note that using extended event windows would obviously increase the probability of potentially overlapping and concurrent event to distort the results.
} 
On the day of announcement of the deals (Day 0), the bidding firms earn a positive and highly significant $2.46 \%$ abnormal return. The results represent acquiring firm shareholders' perception of expected positive synergistic wealth gains from the mergers [see also Savor and Lu, 2009). In economic terms, the results suggest $\$ 49.5$ million in acquirers' market value on Day-0. The positive impact is also shown in larger event windows such as the CAAR $(-3,+3)$ and CAAR $(-5,+5)$. Similarly, the mean value of the market-adjusted cumulative average abnormal return (MCAAR) for $-2+2$ is 0.058 and a t-test (13.48) indicates that MCAAR is significantly different from zero.

\section{Empirical results and discussion of findings}

\subsection{The effect of using stock-financed or cash-financed acquisitions on firm performance}

In this section, we follow Tao et al. (2017) empirical method to test our hypotheses. ${ }^{9}$ First, we examine the impact of M\&A on short-term firm performance relating to choice of payment. Table 3 reports our empirical results of five different event windows based on acquiring firms paying either by stock or cash.

\section{[Insert Table 3 here]}

The results show positive abnormal returns and are statistically significant at the $1 \%$ level. These findings support the merger and acquisition trend in the Chinese market (Tao et al., 2017 and Yang et al., 2017). Chi et al. (2011) suggest that positive announcement returns is attributable to low M\&A competition in China. However, the results are contrary to the findings in many developed markets where acquirers report negative and statistically significant abnormal returns (e.g., Sudarsanam et al., 1996, Holl and Kyriazis, 1997, and Nnadi and Aghanya, 2018). For the acquiring firms paying with stock, the CAAR ranges from $4.5 \%$ to $14.3 \%$ and are statistically significant for all chosen event windows around the announcement date. For bidders paying with cash, the CAAR ranges from $0.8 \%$ to $1.9 \%$ and are statistically significant. The findings show that market reaction to firms acquiring with stock is more significant than acquiring with cash. This is unexpected as it shows that Chinese investors treat cash financing of merger and acquisition as less of good news. A plausible

\footnotetext{
${ }^{9}$ This is similar to Sudarsanam and Mahate (2003) empirical methodology.
} 
reason could be since cash payment could attract capital gains tax implications, the market may value stock offer to defer taxation.

As shown in Table 3, the mean difference between CAAR of stock and cash is positive and statistically significant at the $10 \%$ level for the periods of $(0,0)$ and $(-1,+1)$. This demonstrates that stock as the deal payment method creates higher announcement returns for shareholders. Thus, the results in Table 3 rejects our hypothesis (1) and indicates that stock acquisition tend to outperform cash acquisition. The results are in line with Yang et al. (2017) which examined the effect of corporate liquidity on M\&A decision in China and find that cash-financed acquisitions underperform stock-financed ones.

\subsection{The effects of government (non-)involvement on acquirers' short-term performance.}

Finally, we analyse the short-term wealth effects of the influence of government and nongovernment involvement in bidder merger activities. Table $4 \mathrm{a}$ presents the result of the empirical analysis.

\section{[Insert Table 4 here]}

The result shows that the CAARs over all the event windows are positive and statistically significant at the $1 \%$ level irrespective of whether acquirers have government involvement or not which suggests that shareholders perceive acquisition as value maximising. The results show that the CAARs of acquirers without the influence of government intervention for all event windows surrounding the announcement are larger than the CAARs of those with government intervention. This indicates that the influence of Chinese government has not yielded substantial positive announcement gains for shareholders. A probable reason could be that shareholders view that government involvement may undermine sensitivities of investment, and thus lower future cash flow and weaken returns (e.g., see Black et al., 2015). However, the mean difference is not statistically significant. The evidence in Table 4 supports Hypothesis (2a), which suggests that shareholders of bidding firms with government involvement in merger activities do not gain more abnormal returns than shareholders of bidding firm without government involvement.

To explore the issue further, we consider effects of financing decision on acquisition with and without government involvement. In Table $4 \mathrm{~b}$, we report the results of the empirical analysis of cash-financed and stock-financed acquisitions with(out) government influence. We find that for government influenced acquisitions, using cash as means of financing decisions generate 
higher abnormal returns of the acquiring shareholders on the announcement date $(0,0)$. However, for the other event windows surrounding the announcement date, $(-1,+1),(-2,+2)$, $(-3,+3)$, and $(-5,+5)$, the mean difference is negative supporting that cash-financed acquisition, is not statistically different from zero, and that shareholders are indifferent on the mode of payment of government influenced acquisitions. For the non-government involved acquisitions, the CAARs for stock-financed acquisitions are higher than cash-financed acquisitions and the mean difference are statistically significant at the $1 \%$ level for all event windows. The results show that there are asymmetric market reactions to the choice of payment used by the nongovernment influenced bidders. The findings imply that stock-financed acquisition creates higher returns for shareholders of Chinese non-government acquirers than cash-financed acquisitions. Thus, the evidence opposes Hypothesis 2c.

\subsection{The effect of acquiring private versus public firms on short-term firm performance}

Next, we examine acquirer shareholders' perception of acquiring privately and publicly held targets. Table 5a shows the results of empirical analysis of the CAAR based on acquisition of public and private firms. The test results show that the CAAR for all the event windows are positive and statistically significant at the $1 \%$ level. The findings show that on average, the CAARs for private acquisitions range from $2.51 \%$ to $7.46 \%$ and are higher than public acquisitions with CAARs ranging from $1.78 \%$ to $6.05 \%$ around the announcement date. In addition, the difference between the CAARs for public acquisition and private acquisition is statistically significant at event windows $(0,0)$ and $(-1,+1)$, suggesting that investors perceive private acquisitions as value maximising deals. Moreover, the results suggest that the performance implications for shareholders of acquiring firms differ depending on the type of acquisition. Bidding for a private firm generate more abnormal returns for the acquirer's shareholders than bidding for publicly held firms. A probable reason is that private firms can be seen as the 'engine of growth of the Chinese economy' (Guariglia et al. 2011, p.80), hence their acquisition will yield significant wealth gain for their shareholders. However, when analysed over 5-day $(-2,+2)$, 7-day $(-3,+3)$ and 11-day $(-5,+5)$, the CAAR mean differences are indistinguishable from zero, suggesting that from 5-day around the announcement event, shareholders of acquiring firms do not consider type of acquisition as substantial event. Overall, our empirical analysis rejects the null hypothesis (3a) and suggests that bidder acquiring private firms will outperform those acquiring public firms. 


\section{[Insert Table 5 here]}

Further, we explore the impact of choice of payment in acquiring private and publicly held targets. In Table 5b, we report the results of public and private acquisitions base on choice of payment. For publicly held acquisitions, we find that the abnormal returns for using cash is greater than using stock as financing decision and their mean difference is not statistically significant. This suggests that there is no significant difference in the choice of payment method used in acquiring public firms. This may be attributable to investors expecting less takeover gains whether using cash or stock as choice of acquisitions of public firms. Thus, our hypothesis $3 \mathrm{~b}$ is accepted. On the contrary, for private acquisitions, CAARs of using stockfinanced deals is greater than it is for cash-financed acquisitions and the mean difference is positive and statistically significant at the $1 \%$ level. Thus, investors perceive that using stock to purchase private acquisition will generate extra wealth than using cash. The result can also be explained from the perspective that bidders acquiring private firms have more valuable investment opportunities, which requires them to generate higher cash flow streams and hence the more eager to use stock to finance acquisitions. Therefore, we reject hypothesis $3 \mathrm{c}$.

\subsection{Robustness checks}

To ensure reliability of our results, robustness checks for the short-term performance are conducted. We employ the market-adjusted cumulative average abnormal returns (MCAARs) for our event study analysis. Table 6 presents the results for hypotheses 1, 2a and 3a. The MCAARs in Panel A are positive and statistically significant at the $1 \%$ level. The positive MCAARs of stock-financed acquisition is higher than cash-financed acquisition and support our findings in Table 3 and confirms that shareholders views stock-financing as better spring board investment decision choice compared to cash payment. The results in panels B and C also corroborate the earlier findings in Tables 4 and 5 respectively.

\section{[Insert Table 6 here]}

\section{Conclusion}

This paper examines the performances of the Chinese acquirer with different financing decisions and targets (private and public). It also explores the influence of government involvement in acquirers' merger activities. Specifically, we find that deals financed by stock 
create more value than those financed with cash. In addition, we find evidence that acquirer shareholders experience higher CAARs on acquiring privately-held target than those acquiring publicly-held targets. Further, we show evidence that acquirers without government involvement report more abnormal returns than bidders with government involvement. Our results demonstrate that: (1) shareholders of Chinese acquiring firms perceive acquisition to be value maximising, (2) shareholders of acquirers using stock as the deal payment method realise superior wealth gains than their cash-paying acquiring counterparts, and (3) shareholder perceive that government involved acquisitions do not generate more value than nongovernment involved acquisitions. Taken together, our study provides new insight on the effect of choice of payment, government involvement, and choice of target on short-term M\&As performance in China.

Our results have implications for business acquisitions in China. For example, acquirers would benefit from considering stock payment option rather than cash. Politically connected firms and the government will improve the wealth of Chinese investors and shareholders by reducing the level of influence on government induced acquisitions.

Finally, our study has some limitations. First, though the research focuses on Chinese firms which are specific to the context of the research, future research should consider other emerging economies, such as countries in Africa, Russia, India, and Indonesia. Second, we investigate only publicly listed firms available in SDC and DataStream, future research could extend to unlisted firms. 


\section{References}

Acemoglu, D., Johnson, S., Kermani, A. and Kwak, J. (2016) 'The value of connections in turbulent times: Evidence from the United States', Journal of Financial Economics, Vol. 121, Issue 2, pp.368-391.

Agrawal A. and Jaffe, J. F. and Mandelker, G. N. (1992) The post-merger performance of acquiring firms: a re-examination of an anomaly. The Journal of Finance, 47(4): 1605-1621.

Aggarwal, R., Samwick, A., 2003. Why Do Managers Diversify Their Firms? Agency Reconsidered. The Journal of Finance, 58(1), 71-118.

Ahlstrom, D., Levitas, E., Hitt, M. A., Dacin, M. T., \& Zhu, H., 2014. The three faces of China: Strategic alliance partner selection in three ethnic Chinese economies. Journal of World Business, 49(4): 572-585.

Alexandridis, G., Petmezas, D., and Travlos, N. G. (2010) 'Gains from mergers and acquisitions around the world: New evidence', Financial Management, Vol. 39, Issue 4, pp.1671-1695.

Ang, J. and Kohers, N. (2001) 'The take-over market for privately held companies: the US experience', Cambridge Journal of Economics, Vol. 25, Issue 6, pp.723-748.

Aw, M. S. B. and Chatterjee, R. A. (2004) The performance of UK firms acquiring large cross-border and domestic takeover targets. Applied Financial Economics, 14(5): 337 349.

Aybar, B. and Ficici, A. (2009) 'Cross-border acquisitions and firm value: an analysis of emerging-market multinationals. Journal of International Business Studies, Vol. 40, Issue 8, pp.1317-1338.

Baker, H.K., Dutta, S., Saadi, S. and Zhu, P. (2012) Are good performers bas acquirers? Financial Management, 95-118

Barai P, and Mohanty, P. (2010) Short term performance of Indian acquirers-effects of mode of payment, industry relatedness and status of target. Industry Relatedness and Status of Target (October 25).

Bena, J., and Li, K., 2014. Corporate innovations and mergers and acquisitions. The Journal of Finance, 69(5), 1923-1960.

Black, E.L., Doukas, A.J., Xing, X. and Guo, J. (2015) 'Gains to Chinese bidder firms: domestic vs. foreign acquisitions', European Financial Management, Vol. 21, Issue 5, pp.905-935.

Boateng, A. and Bi, X. G. (2013) Acquirer characteristics and method of payment: evidence from Chinese mergers and acquisitions. Managerial and Decision Economics, 35(8): 540-554.

Boehmer, E., Masumeci, J, and Poulsen, A. B. (1991) 'Event-study methodology under conditions of event-induced variance', Journal of financial economics, Vol. 30, Issue 2, pp.253-272.

Brown, S. J, \& Warner, J. B. (1985) 'Using daily stock returns: The case of event studies', Journal of financial economics, Vol. 14, Issue 1, pp.3-31.

Bruner, R. (2004) Where M\&A pays and where it strays: a survey of the research. Journal of Applied Corporate Finance, 16(4): 63-76. 
Burkart, M. and Lee, S. (2016) 'Smart Buyers', Review of Corporate Finance Studies, 5 (2): $239-270$.

Calomiris, C. W., Fisman, R. \& Wang, Y. (2010) Profiting from government stakes in a command economy: Evidence from Chinese asset sales. Journal of Financial Economics, 96(3): 399-412.

Campa, J. M, and Hernando, I. (2004) Shareholder value creation in European M\&As. European Financial Management, 10(1): 47-81.

Capen, E. C., Clapp, R. V. and Campbell, W. M. (1971) 'Competitive bidding in high-risk situations', Journal of Petroleum Technology, Vol. 23, Issue 6, pp.641-653.

Capron, L., and Shen, J. C. 2007. Acquisitions of private versus public firms: Private information, target selection, and acquirer returns. Strategic Management Journal, 28(9): 891-911.

Chen, Y. Y. and Young, M. N. (2010) 'Cross-border mergers and acquisitions by Chinese listed companies: A principal-principal perspective', Asia Pacific Journal of Management, Vol. 27, Issue 3, pp.523-539.

Chi, J., Sun, Q. and Young, M. (2011) 'Performance and characteristics of acquiring firms in the Chinese stock markets', Emerging Markets Review, Vol. 12, Issue 2, pp.152170 .

Cho, H. and Ahn, S. (2017). 'Stock payment and the effects of institutional and cultural differences: A study of shareholder value creation in cross-border M\&As', International Business Review, Vol. 26, Issue 3, pp.461-475.

Chui, A. C. W. \& Kwok, C. C.Y. (1998) Cross-autocorrelation between A shares and B shares in the Chinese stock market. Journal of Financial Research, Vol. 21, Issue 3, pp.333-353.

Conn, R .L, Cosh, A., Guest, P. M., et al. (2005) The impact on UK acquirers of domestic, cross-border, public and private acquisitions. Journal of Business Finance \& Accounting, 32(5-6): 815-870.

Corrado, C. J. \& Truong, C. (2008) Conducting event studies with Asia-Pacific security market data. Pacific-Basin Finance Journal, 16(5): 493-521.

Corrado, C. J. A. (1989) nonparametric test for abnormal security-price performance in event studies. Journal of financial economics, 23(2): 385-395.

Del Bo, C.D., Ferraris, M. and Florio, M. (2017) 'Governments in the market for corporate control: Evidence from M\&A deals involving state-owned enterprises', Journal of Comparative Economics, Vol. 45, Issue 1, pp.89-109.

Deng, P. (2004) 'Outward investment by Chinese MNCs: motivations and implications', Business Horizon, Vol. 47, Issue 3, pp.8-16.

Draper, P. \& Paudyal, K. (2006) Acquisitions: private versus public. European Financial Management, 12(1): 57-80.

Dutta, S., Jog, V., 2009. The long-term performance of acquiring firms: A re-examination of an anomaly. Journal of Banking \& Finance, Vol. 33, 1400-1412.

Dutta, S., Saadi, S. and Zhu, P. (2013) 'Does payment method matter in cross-border acquisitions?' International Review of Economics and Finance, Vol. 25, pp.91-107. 
Eckbo, E., Makaew, T., Thornburn, K. (2018) 'Are stock-financed takeovers opportunistic?' Journal of Financial Economics, pp.1-23 (forthcoming). https://doi.org/10.1016/j.jfineco.2018.03.006.

Eckbo, B. E. and Thorburn, K. S. (2000) Gains to bidder firms revisited: Domestic and foreign acquisitions in Canada. Journal of Financial and Quantitative Analysis, 35(01): $1-25$.

Erel, I., Liao, R., Weisbach, M., 2012. Determinants of Cross-Border Mergers and Acquisitions. The Journal of Finance, 67(3), 1045-1082.

Faccio, M. and Masulis, R.W. (2005) 'The choice of payment method in European mergers and acquisitions', Journal of Finance. Vol. 60, Issue 3, pp.1345-1388.

Faccio, M., Stolin, D, \& McConnell, J. J. (2006) Returns to acquirers of listed and unlisted targets. Journal of Financial and Quantitative Analysis, 41 (1), 197-220.

Fama, E. F. (1970) 'Efficient Capital Markets: A Review of Theory and Empirical Work', The Journal of Finance, Vol. 25, No. 2, pp.383-417.

Fan, J.P.H., Wei, K.C.J. and Xu, X. (2011) 'Corporate finance and governance in emerging markets: a selective review and an agenda for future research', Journal of Corporate Finance, Vol. 17, Issue 2, pp.207-214.

Faulkender, M. and Wang, R. (2006) 'Corporate financial policy and the value of cash', Journal of Finance, Vol. 61, Issue 4, pp.1957-1990.

Firth, M., Lin, C. and Wong, S. (2008) 'Leverage and investment under a state-owned bank lending environment: Evidence from China', Journal of Corporate Finance, Vol. 14, Issue 5, pp.642-653.

Fischer, M., 2017. The source of financing in mergers and acquisitions. The Quarterly Review of Economics and Finance, Vol. 65, 227-239.

Frye, T., \& Shleifer, A. 1997. The invisible hand and the grabbing hand. American Economic Review, 87 (2), 354-358.

Fu, F., Lin, L. and Officer, M. S. (2013) 'Acquisitions driven by stock overvaluation: Are they good deals?' Journal of Financial Economics, Vol. 109, Issue 1, 24-39.

Fuller, K., Netter, J. and Stegemoller, M. (2002) 'What Do Returns to Acquiring Firms Tell Us? Evidence from Firms That Make Many Acquisitions', Journal of Finance, Vol. 57, Issue 4, pp.1763-1794.

Gaughan, P.A. (2002), Mergers, Acquisition, and Corporate Restructuring, Wiley, New York, NY.

Goergen, M. and Renneboog, L. (2004) Shareholder Wealth Effects of European Domestic and Cross-border Takeover Bids. European Financial Management, 10(1): 9-45.

Grossman, S.J. and Stiglitz, J.E. (1980) 'On the impossibility of informationally efficient markets', The American Economic Review, Vol. 70, Issue 3, pp.393-408.

Guariglia, A., Liu, X., Song, L. (2011) 'Internal finance and growth: Microeconometric evidence on Chinese firms', Journal of Development Economics, Vol. 96, Issue 1, pp.79-94.

Gubbi, S. R., Aulakh, P. S., Ray, S, et al. (2010) Do international acquisitions by emergingeconomy firms create shareholder value? The case of Indian firms. Journal of 
International Business Studies, 41(3): 397-418.

Harford, J., Klasa, S. and Walcott, N. (2009) 'Do firms have leverage targets? Evidence from acquisitions', Journal of Financial Economics, Vol. 93, Issue 1, pp.1-14.

Harrison, J.S., Hitt, M.A. and Ireland, D.R. (2001) 'Resource complementarity in business combinations: Extending the logic to organizational alliances', Journal of Management, Vol. 27, Issue 6, pp.679-690.

Heckman, J. (1979) 'Sample selection bias as a specification error', Econometrica, Vol. 47, Issue 1, pp.153-162.

Hiller, N., Hambrick, D. (2005) 'Conceptualizing executive hubris: the role of (hyper-) core self-evaluations in strategic decision-making', Strategic Management Journal, Vol. 26, Issue 4, pp.297-319.

Holl, P. \& Kyriazis, D. (1997) Wealth creation and bid resistance in UK takeover bids. Strategic Management Journal, Vol. 18, Issue 6, pp.483-498.

Jensen, M. C. and Ruback, R. S. (1983) The market for corporate control: The scientific evidence. Journal of Financial Economics, 11(1): 5-50.

John, K., Freund, S., Nguyen, D., Vasudevan, G.K. (2010), 'Investor protection and crossborder acquisitions of private and public targets', Journal of Corporate Finance, Vol. 16, Issue 3, pp.259-275.

Karels, G. V., Lawrence, E. and Yu, J. (2011) Cross-border mergers and acquisitions between industrialized and developing countries: US and Indian merger activity. International Journal of Banking and Finance, 8(1): 3.

Kiesel, F., Ries, J., Tielmann, A. (2017) 'Reprint of "The impact of mergers and acquisitions on shareholders' wealth in the logistics service industry', International Journal of Production Economics, Vol. 194, pp. 261-277.

King, D.R., Dalton, D.R., Daily, C.M. and Covin, J.G. (2004) 'Meta-analyses of postacquisition performance: indications of unidentified moderators', Strategic Management Journal, Vol. 25, Issue 2, pp.187-200.

Lebedev, S., Peng, M. W., Xie, E., and Stevens, C. E. (2015) 'Mergers and acquisitions in and out of emerging economies', Journal of World Business, Vol. 50, Issue 4, pp.651662.

Leeth, J. D. and Borg, J. R. (2000) The impact of takeovers on shareholder wealth during the 1920s merger wave. Journal of Financial and Quantitative Analysis, 35(02): 217-238.

Lowinski, F, and Schiereck, D, and Thomas, T. W. (2004) The effect of cross-border acquisitions on shareholder wealth - evidence from Switzerland. Review of Quantitative Finance and Accounting, 22(4): 315-330.

Lin, S., Ye, H., 2018. Foreign Direct Investment, Trade Credit, and Transmission of Global Liquidity Shocks: Evidence from Chinese Manufacturing Firms. The Review of Financial Studies, Vol 31, Issue 1, pp.206-238.

Mantecon, T. (2008) 'An analysis of the implications of uncertainty and agency problems on the wealth effects to acquirers of private firms', Journal of Banking and Finance, Vol 32, Issue 5, pp.892-905.

Martin, K. J. (1996) 'The method of payment in corporate acquisitions, investment opportunities, and management ownership', Journal of Finance, Vol. 51, Issue 4, pp.1227-1246. 
Moeller, S. B., Schlingemann, F. P. and Stulz, R. M. (2005) Wealth destruction on a massive scale? A study of acquiring-firm returns in the recent merger wave. The Journal of Finance, 60(2): 757-782.

Morck, R., Yeung, B. and Zhao, M. (2008) 'Perspectives on China's outward foreign direct investment', Journal of International Business Studies, Vol. 39, Issue 3, pp.337-350.

Myers, S. C. \& Majluf, N. S. (1984) 'Corporate financing and investment decisions when firms have information that investors do not have', Journal of financial economics, 13(2): 187-221.

Nnadi, M. and Aghanya, D. (2018) 'Evaluation of merger premium and firm performance in Europe', International Journal of Banking, Accounting and Finance 9(2), 119-140.

Piotroski, J., Wong, J. 2012. Institutions and information environment of Chinese listed firms. In: Fan, J., Morck, R. (Eds.), Capitalizing China, pp. 242-246, University of Chicago Press, Chicago.

Rani, N., Yadav, S. S. and Jain, P. K. (2013) Market response to the announcement of mergers and acquisitions: an empirical study from India. The Journal of Business Perspective, 17(1): 1-16.

Rau, P. R., Vermaelen, T. and Glamour, R. (1998) Value and the post-acquisition

performance of acquiring firms. Journal of Financial Economics, 49(2): 223-253.

Savor, P. and Lu, Q. (2009) 'Do stock mergers create value for acquirers? The Journal of

Finance, Vol. 64, Issue 3, pp.1061-1097.

Schwert, G.W. (1981) 'Using financial data to measure effects of regulation', The Journal of Law and Economics, Vol. 24, Issue 1, pp.121-158.

Shen, J., 2006. Acquisitions of private versus public firms: the role of private information on acquirer returns. Academy of Management Best Conference Paper, T1-T6.

Smith, R. L. and Kim, J. H. (1994) The combined effects of free cash flow and financial slack on bidder and target stock returns. Journal of Business, 281-310.

Sudarsanam, S, Holl, P. \& Salami, A. (1996) 'Shareholder wealth gains in mergers: effect of synergy and ownership structure', Journal of Business Finance \& Accounting, Vol. 23, Issue 5/6, PP.673-698.

Sudarsanam, S. and Mahate, A. (2003) 'Glamour Acquirers, Method of Payment and Postacquisition Performance: The UK Evidence', Journal of Business Finance and Accounting, Vol. 30, Issue 1\&2, pp.299-341.

Tao, F., Liu, X. and Xia, E. (2017) 'Do cross-border mergers and acquisitions increase short-term market performance? The case of Chinese firms', International Business Review, Vol. 26, Issue 1, pp.189-202.

Thanos, I.C. and Papadakis, V.M. (2012) 'Unbundling acquisition performance: how do they perform and how can this be measured?' In: Faulkner, D., Teerikangas, S. and Joseph, R.J. (Eds.), Handbook of Mergers and Acquisitions, pp. 114-147. Oxford University Press, Oxford UK.

Thompson Reuters, (2010) 'Mergers and acquisitions financial advisory review', Thompson Reuters.

Thompson Reuters, (2017) 'Mergers and acquisitions financial advisory review', Thompson Reuters. 
Travlos, N. G. (1987) 'Corporate takeover bids, methods of payment, and bidding firms' stock returns', The Journal of Finance, Vol.42, Issue 4, pp.943-963.

UNCTAD, 2017. World Investment Report: Investment and the Digital Economy. New York and Geneva: United Nations.

Walker, M. M. (2000) Corporate takeovers, strategic objectives, and acquiring-firm shareholder wealth. Financial Management, 53-66.

Wan, W., Yiu, D. (2009) 'Research notes and commentaries: From crisis to opportunity: environmental jolt, corporate acquisitions, and firm performance', Strategic Management Journal, Vol. 30, Issue 7, pp 791-801.

Wang, C.Q., Hong, J.J., Kafouros, M. \& Wright, M. (2012) 'Exploring the role of government involvement in outward FDI from emerging economies', Journal of International Business Studies, Vol. 43, Issue 7, pp.655-676.

Wulf, J.M. (2004) 'Do CEOs in mergers trade power for premium? Evidence from mergers of equals', Journal of Law Economics and Organization, Vol. 20, Issue 1, pp.60-101.

Yang, J., Guariglia, A. and Guo, J. (2017) 'To what extent does corporate liquidity affect M\&A decisions, method of payment and performance? Evidence from China', Journal of Corporate Finance, (forthcoming). https://doi.org/10.1016/j.jcorpfin.2017.09.012.

Ye, C. and Yuan, H., (2014) Does Payment Method Of Mergers And Acquisitions Matter? An Examination Of The Medical Industry in China. Journal of Advanced Studies in Finance, $5(1$ (9), 37.

Zhou, B., Guo, M., Hua, J. and Doukas, A. (2015) 'Does State Ownership Drive M\&A Performance? Evidence from China', European Financial Management, Vol. 21, No. 1, pp.79-105.

Zhu, P. and Malhotra, S. (2008) Announcement effect and price pressure: An empirical study of cross-border acquisitions by Indian firms. International Research Journal of Finance and Economics, 13(1): 24-41.

Zhou, C., Xie, J. and Wang, Q. (2016) 'Failure to Complete Cross-Border M\&As: "To" vs. "From" Emerging Markets', Journal of International Business Studies, Vol. 47, Issue 9, pp.1077-1105. 
Table 1a

Panel A. Sample distribution by announcement year

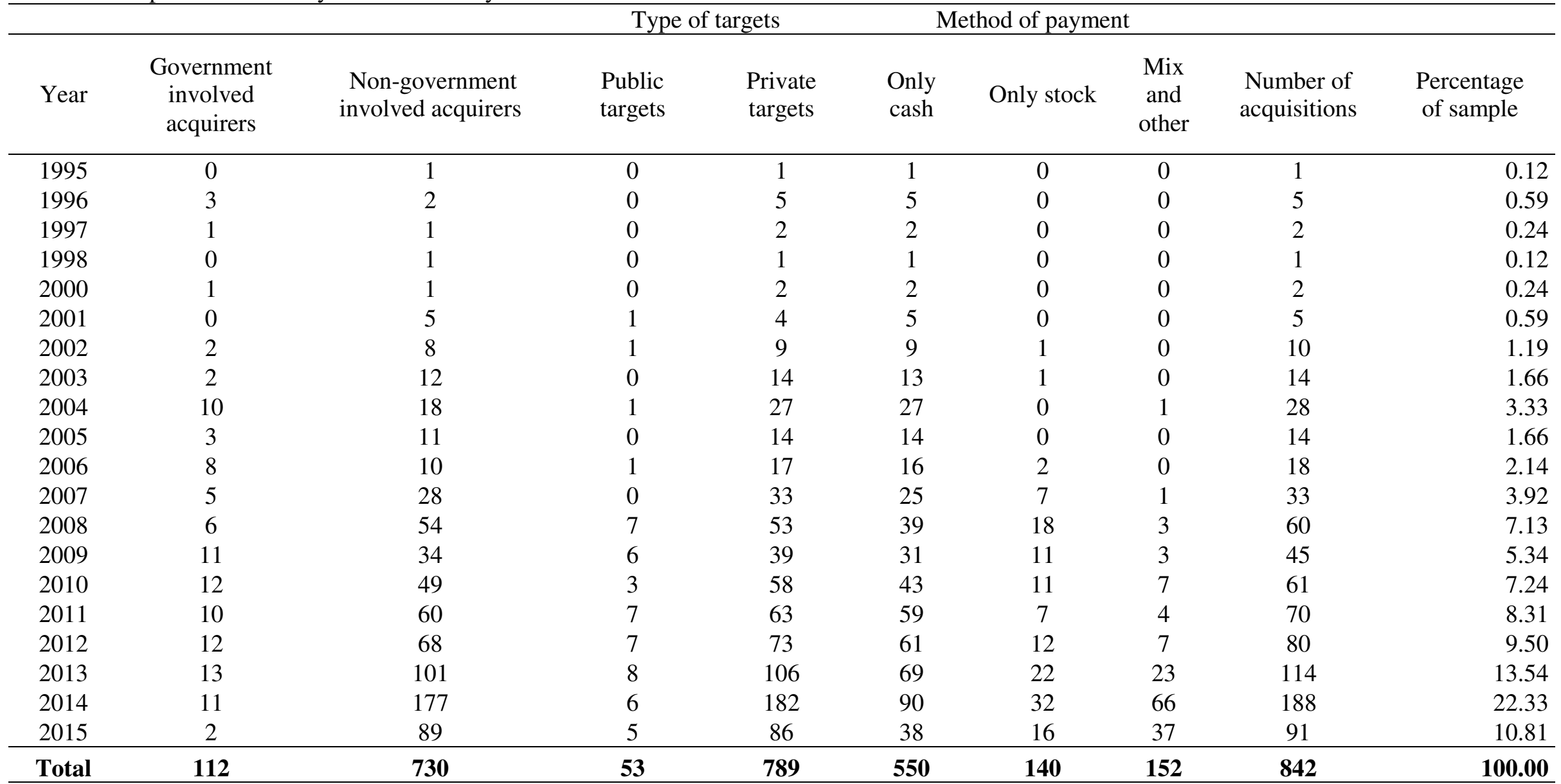

Note: The sample consists of 854 completed China mergers and acquisitions (listed in SDC) between January 1993 and June 2015 . Cash and stock represent the number of deals with each method and mix is a combination of cash and stock. The sample period is from 1993 to 2015 . Table $1 \mathrm{~b}$ presents, by industry, the fraction of acquiring firms. Industry data are classified using DataStream Industrial Classification Benchmark (ICB) indices (level 1) that sorts firms into ten super-sectors. Table 1c presents, by type of acquisition and nature of government involvement in acquisition. 
Table 1b. Industry distribution of acquiring firms

\begin{tabular}{lrrr}
\hline Acquirers' industry category & N & \% of sample & $\begin{array}{c}\text { Acquirer average } \\
\text { market value (\$'m) }\end{array}$ \\
\hline Industrials & 285 & 33.85 & 1,032 \\
Consumer Goods & 150 & 17.81 & 825 \\
Basic Materials & 126 & 14.96 & 1,985 \\
Financials & 67 & 7.96 & 6,164 \\
Technology & 63 & 7.48 & 923 \\
Consumer Services & 60 & 7.13 & 1,233 \\
Health Care & 51 & 6.06 & 890 \\
Utilities & 23 & 2.73 & 837 \\
Oil \& Gas & 15 & 1.78 & 27,715 \\
Telecommunications & 2 & 0.24 & 818 \\
Total & $\mathbf{8 4 2}$ & $\mathbf{1 0 0 . 0 0}$ & $\mathbf{2 , 0 1 3}$ \\
\hline
\end{tabular}

Table 1c. Distribution of acquiring firms by type of acquisitions and government involvement

\begin{tabular}{lrr}
\hline Involvement & \multicolumn{2}{c}{$\begin{array}{c}\text { Acquirer average } \\
\text { market value (\$'m) }\end{array}$} \\
\hline Acquirers without government involvement & 730 & 1,199 \\
Acquirers with government involvement & 112 & 7,319 \\
Type of acquisition & & \\
Private acquisition & & 2,026 \\
Public acquisition & 789 & 1,816 \\
\hline
\end{tabular}

Table 2. Summary statistics

The table summarises market reaction to M\&A announcements of Chinese acquirers.

\begin{tabular}{ccccccccc}
\hline Variable & Mean & Stdev & t-stat & P25 & P50 & P75 & $\begin{array}{c}\text { Positive/ } \\
\text { negative }\end{array}$ & $\begin{array}{c}\text { \% } \\
\text { positive }\end{array}$ \\
\hline CAAR $(0,0)$ & $0.0246 * * *$ & 0.0490 & 14.629 & -0.0083 & 0.0088 & 0.0682 & $523: 319$ & 62.1 \\
CAAR $(-1,+1)$ & $0.0418 * * *$ & 0.0877 & 13.887 & -0.0138 & 0.0156 & 0.0945 & $527: 315$ & 62.6 \\
CAAR(-2, +2) & $0.0552 * * *$ & 0.1181 & 13.599 & -0.0164 & 0.0205 & 0.1135 & $522: 320$ & 62.0 \\
CAAR(-3,+3) & $0.0650 * * *$ & 0.1441 & 12.976 & -0.0231 & 0.0237 & 0.1136 & $520: 322$ & 61.8 \\
CAAR(-5, +5) & $0.0737 * * *$ & 0.1811 & 11.839 & -0.0292 & 0.0199 & 0.1147 & $507: 335$ & 60.2 \\
MCAAR(0, 0) & $0.0253 * * *$ & 0.0491 & 14.871 & -0.0079 & 0.0097 & 0.0716 & $527: 315$ & 62.6 \\
MCAAR(-1,+1) & $0.0438 * * *$ & 0.0881 & 13.717 & -0.0135 & 0.0173 & 0.0956 & $537: 305$ & 63.8 \\
MCAAR(-2, +2) & $0.0584 * * *$ & 0.1181 & 13.481 & -0.0171 & 0.0233 & 0.1145 & $536: 306$ & 63.7 \\
MCAAR(-3,+3) & $0.0694 * * *$ & 0.1435 & 12.052 & -0.0201 & 0.0264 & 0.1208 & $544: 298$ & 64.6 \\
MCAAR $(-5,+5)$ & $0.0824 * * *$ & 0.1803 & 10.963 & -0.0269 & 0.0280 & 0.1286 & $519: 323$ & 61.6 \\
\hline
\end{tabular}


Table 3. Market reaction: Stock payment vs. cash payment

\begin{tabular}{|c|c|c|c|c|c|c|c|c|c|c|c|c|}
\hline & & & Stock & ayment & & & & Cash & ayment & & & \\
\hline Event window & $\mathrm{N}$ & CAAR & t-Stat & Boehmer & $\begin{array}{c}\text { Corrado } \\
\text { rank }\end{array}$ & $\mathrm{N}$ & CAAR & $\mathrm{t}-$ Stat & Boehmer & $\begin{array}{l}\text { Corrado } \\
\text { rank }\end{array}$ & $\begin{array}{c}\text { Mean } \\
\text { Difference }\end{array}$ & t-test \\
\hline $\operatorname{CAAR}(0,0)$ & 140 & $0.0449 * * *$ & 9.502 & 9.404 & 7.757 & 550 & $0.0084 * * *$ & 5.065 & 4.659 & 4.022 & 0.0365 & $2.252^{* * *}$ \\
\hline $\operatorname{CAAR}(-2,+2)$ & 140 & $0.1006 * * *$ & 8.524 & 8.605 & 7.701 & 550 & $0.0172 * * *$ & 4.721 & 4.569 & 2.452 & 0.0834 & 1.574 \\
\hline $\operatorname{CAAR}(-3,+3)$ & 140 & $0.1224 * * *$ & 8.342 & 8.290 & 7.822 & 550 & $0.0182 * * *$ & 4.238 & 4.126 & 1.603 & 0.1042 & 1.540 \\
\hline $\operatorname{CAAR}(-5,+5)$ & 140 & $0.1432 * * *$ & 7.323 & 7.342 & 6.526 & 550 & $0.0189 * * *$ & 3.698 & 3.660 & 0.565 & 0.1243 & 1.297 \\
\hline
\end{tabular}

$* * *, * *$, and $*$ indicate statistical significance at the $1 \%, 5 \%$ and $10 \%$ levels respectively using t-statistics.

Table 4a. Market reaction: Acquirer with government involvement vs. Acquirer without government involvement Acquirers with government involvement

Acquirers without government involvement

Mean Difference

\begin{tabular}{|c|c|c|c|c|c|c|c|c|c|c|c|c|}
\hline Event window & $\mathrm{N}$ & CAAR $_{\mathrm{G}}$ & $\mathrm{t}-$ Stat & Boehmer & $\begin{array}{c}\text { Corrado } \\
\text { Rank }\end{array}$ & $\mathrm{N}$ & $\mathrm{CAAR}_{\mathrm{NG}}$ & $\mathrm{t}-\mathrm{Stat}$ & Boehmer & $\begin{array}{c}\text { Corrado } \\
\text { Rank }\end{array}$ & $\begin{array}{l}\mathrm{CAAR}_{\mathrm{G}}- \\
\mathrm{CAAR}_{\mathrm{NG}}\end{array}$ & t-test \\
\hline CAAR $(0,0)$ & 112 & $0.0207 * * *$ & 4.983 & 4.605 & 5.455 & 730 & $0.0261 * * *$ & 13.762 & 13.354 & 9.418 & -0.0054 & 0.125 \\
\hline CAAR $(-1,+1)$ & 112 & $0.0368 * * *$ & 4.815 & 4.740 & 4.956 & 730 & $0.0449 * * *$ & 13.021 & 12.701 & 8.722 & -0.0081 & 0.099 \\
\hline $\operatorname{CAAR}(-2,+2)$ & 112 & $0.0447 * * *$ & 4.541 & 4.565 & 4.124 & 730 & $0.0605 * * *$ & 12.817 & 12.467 & 8.480 & -0.0157 & 0.144 \\
\hline $\operatorname{CAAR}(-3,+3)$ & 112 & $0.0523 * * *$ & 4.510 & 4.525 & 3.768 & 730 & $0.0720 * * *$ & 12.173 & 11.851 & 7.905 & -0.0197 & 0.156 \\
\hline $\operatorname{CAAR}(-5,+5)$ & 112 & $0.0668 * * *$ & 4.629 & 4.519 & 3.635 & 730 & $0.0848 * * *$ & 10.941 & 10.687 & 6.088 & -0.0180 & 0.119 \\
\hline
\end{tabular}

$* * *, * *$, and $*$ indicate statistical significance at the $1 \%, 5 \%$ and $10 \%$ levels respectively using t-statistics. 
Table 4b. Cash and stock CAR difference test results for Acquirer with government involvement vs. Acquirer without government involvement.

\begin{tabular}{|c|c|c|c|c|}
\hline \multicolumn{5}{|c|}{ Acquirers with government involvement } \\
\hline \multicolumn{5}{|c|}{ CAR } \\
\hline Event window & Stock & Cash & Mean difference & t-test \\
\hline $\operatorname{CAAR}(0,0)$ & 0.0135 & 0.0395 & $-0.0260 * *$ & -2.384 \\
\hline CAAR $(-1,+1)$ & 0.0288 & 0.0654 & -0.0366 & -1.592 \\
\hline CAAR $(-2,+2)$ & 0.0341 & 0.0803 & -0.0462 & -1.403 \\
\hline CAAR $(-3,+3)$ & 0.0395 & 0.0917 & -0.0522 & -1.252 \\
\hline CAAR $(-5,+5)$ & 0.0507 & 0.1035 & -0.0528 & -0.958 \\
\hline \multicolumn{5}{|c|}{ Acquirers without government involvement } \\
\hline Event window & Stock & Cash & Mean difference & t-test \\
\hline $\mathrm{CAAR}(0,0)$ & 0.1326 & 0.0127 & $0.1199 * * *$ & 6.151 \\
\hline CAAR $(-1,+1)$ & 0.1178 & 0.0136 & $0.1042 * * *$ & 6.799 \\
\hline $\operatorname{CAAR}(-2,+2)$ & 0.0988 & 0.0139 & $0.0849 * * *$ & 6.655 \\
\hline $\operatorname{CAAR}(-3,+3)$ & 0.0777 & 0.0103 & $0.0674 * * *$ & 7.211 \\
\hline $\operatorname{CAAR}(-5,+5)$ & 0.0431 & 0.0074 & $0.0357 * * *$ & 6.822 \\
\hline
\end{tabular}


Table 5a. Market reaction: Public acquisition vs private acquisition

\begin{tabular}{|c|c|c|c|c|c|c|c|c|c|c|c|c|}
\hline & \multicolumn{6}{|c|}{ Public acquisition } & \multicolumn{4}{|c|}{ Private acquisition } & \multicolumn{2}{|c|}{ Mean difference } \\
\hline Event window & $\mathrm{N}$ & $\mathrm{CAAR}_{\mathrm{PU}}$ & t-Stat & Boehmer & $\begin{array}{c}\text { Corrado } \\
\text { rank }\end{array}$ & $\mathrm{N}$ & CAAR $_{P R}$ & t-Stat & Boehmer & $\begin{array}{l}\text { Corrado } \\
\text { rank }\end{array}$ & $\begin{array}{l}\text { CAARPU -- } \\
\text { CAAR }_{P R}\end{array}$ & t-test \\
\hline $\operatorname{CAAR}(0,0)$ & 53 & $0.0178 * * *$ & 2.731 & 2.934 & 3.106 & 789 & $0.0251 * * *$ & 14.394 & 13.816 & 10.023 & $-0.0073 * * *$ & -2.939 \\
\hline $\operatorname{CAAR}(-2,+2)$ & 53 & $0.0466 * * *$ & 2.664 & 2.837 & 2.805 & 789 & $0.0558 * * *$ & 13.367 & 12.973 & 8.794 & -0.0092 & -0.984 \\
\hline $\operatorname{CAAR}(-3,+3)$ & 53 & $0.0584 * * *$ & 2.814 & 2.889 & 2.785 & 789 & $0.0655 * * *$ & 12.674 & 12.351 & 8.143 & -0.0071 & -1.074 \\
\hline $\operatorname{CAAR}(-5,+5)$ & 53 & $0.0605 * * *$ & 2.440 & 2.549 & 2.114 & 789 & $0.0746 * * *$ & 11.591 & 11.307 & 6.490 & -0.0141 & -0.421 \\
\hline
\end{tabular}

$* * *, * *$, and $*$ indicate statistical significance at the $1 \%, 5 \%$ and $10 \%$ levels respectively using t-statistics. 
Table 5b. Cash and stock CAR difference for public acquisition vs private acquisition

\begin{tabular}{|c|c|c|c|c|}
\hline \multicolumn{5}{|c|}{ Public acquisition } \\
\hline \multicolumn{5}{|c|}{ CAR } \\
\hline Event window & Stock & Cash & Mean difference & t-test \\
\hline $\mathrm{CAAR}(0,0)$ & 0.0103 & 0.0151 & -0.0048 & -0.160 \\
\hline $\operatorname{CAAR}(-1,+1)$ & 0.0093 & 0.0258 & -0.0165 & -0.215 \\
\hline $\operatorname{CAAR}(-2,+2)$ & 0.0662 & 0.032 & 0.0342 & 0.314 \\
\hline $\operatorname{CAAR}(-3,+3)$ & 0.0922 & 0.0427 & 0.0495 & 0.408 \\
\hline $\operatorname{CAAR}(-5,+5)$ & 0.1560 & 0.0324 & 0.1236 & 0.742 \\
\hline \multicolumn{5}{|c|}{ Private acquisition } \\
\hline Event window & Stock & Cash & Mean difference & t-test \\
\hline CAAR $(0,0)$ & 0.0441 & 0.0078 & $0.0363 * * *$ & 7.531 \\
\hline $\operatorname{CAAR}(-1,+1)$ & 0.0792 & 0.0122 & $0.0670 * * *$ & 7.916 \\
\hline $\operatorname{CAAR}(-2,+2)$ & 0.0980 & 0.0158 & $0.0822 * * *$ & 7.066 \\
\hline $\operatorname{CAAR}(-3,+3)$ & 0.1157 & 0.0157 & $0.1000 * * *$ & 7.046 \\
\hline $\operatorname{CAAR}(-5,+5)$ & 0.1280 & 0.0175 & $0.1105 * * *$ & 6.147 \\
\hline
\end{tabular}


Table 6. Investor reaction using market cumulative average abnormal returns (MCAAR)

\begin{tabular}{|c|c|c|c|c|c|c|c|c|c|c|c|c|}
\hline \multirow{2}{*}{$\begin{array}{l}\text { Panel A. } \\
\text { Event window }\end{array}$} & \multicolumn{6}{|c|}{ Stock payment } & \multicolumn{4}{|c|}{ Cash payment } & \multicolumn{2}{|c|}{ Mean difference } \\
\hline & $\mathrm{N}$ & $\mathrm{CAAR}_{\mathrm{PU}}$ & t-Stat & Boehmer & $\begin{array}{c}\text { Corrado } \\
\text { rank }\end{array}$ & $\mathrm{N}$ & CAAR $_{P R}$ & t-Stat & Boehmer & $\begin{array}{c}\text { Corrado } \\
\text { rank }\end{array}$ & $\begin{array}{l}\text { MCAAR } \\
\text { MCAAR }\end{array}$ & t-test \\
\hline $\operatorname{MCAAR}(0,0)$ & 140 & $0.0435 * * *$ & 9.135 & 9.440 & 7.448 & 550 & $0.0087 * * *$ & 5.147 & 4.316 & 4.066 & $0.0348 * *$ & 2.169 \\
\hline $\operatorname{MCAAR}(-1,+1)$ & 140 & $0.0773 * * *$ & 9.667 & 9.343 & 8.123 & 550 & $0.0147 * * *$ & 4.217 & 4.652 & 2.869 & $0.0626^{*}$ & 1.797 \\
\hline $\operatorname{MCAAR}(-2,+2)$ & 140 & $0.0989 * * *$ & 8.145 & 8.113 & 7.787 & 550 & $0.0197 * * *$ & 4.117 & 4.236 & 2.375 & 0.0792 & 1.501 \\
\hline $\operatorname{MCAAR}(-3,+3)$ & 140 & $0.1192 * * *$ & 8.443 & 8.343 & 7.558 & 550 & $0.0221 * * *$ & 4.254 & 4.211 & 1.570 & 0.0970 & 1.434 \\
\hline $\operatorname{MCAAR}(-5,+5)$ & 140 & $0.1325 * * *$ & 7.123 & 7.333 & 6.391 & 550 & $0.0255^{* * *}$ & 3.462 & 3.866 & 0.757 & 0.1070 & 1.151 \\
\hline Panel B. & & Acquirers & vith gov & rnment in & lvement & & Acquirers v & ithout go & ernment in & olvement & & \\
\hline $\operatorname{MCAAR}(0,0)$ & 112 & $0.0205^{* * *}$ & 4.841 & 4.336 & 5.168 & 730 & $0.0253 * * *$ & 13.747 & 12.921 & 9.404 & -0.0048 & -0.111 \\
\hline $\operatorname{MCAAR}(-1,+1)$ & 112 & $0.0380 * * *$ & 4.796 & 4.533 & 4.234 & 730 & $0.0424 * * *$ & 12.615 & 12.891 & 8.231 & -0.0044 & -0.053 \\
\hline $\operatorname{MCAAR}(-2,+2)$ & 112 & $0.0478 * * *$ & 4.365 & 3.733 & 3.930 & 730 & $0.0564 * * *$ & 12.625 & 11.716 & 7.859 & -0.0086 & -0.079 \\
\hline $\operatorname{MCAAR}(-3,+3)$ & 112 & $0.0546 * * *$ & 4.611 & 4.525 & 3.758 & 730 & $0.0666 * * *$ & 11.245 & 10.895 & 7.257 & -0.0121 & -0.096 \\
\hline $\operatorname{MCAAR}(-5,+5)$ & 112 & $0.0686 * * *$ & 4.629 & 4.619 & 3.628 & 730 & $0.0745 * * *$ & 10.290 & 10.498 & 5.639 & -0.0060 & -0.039 \\
\hline Panel C. & & & Public a & quisition & & & & Private & quisition & & & \\
\hline $\operatorname{MCAAR}(0,0)$ & 53 & $0.0184 * * *$ & 2.663 & 2.669 & 3.311 & 789 & $0.0258 * * *$ & 14.129 & 13.445 & 10.242 & $-0.0074 * * *$ & -6.050 \\
\hline $\operatorname{MCAAR}(-1,+1)$ & 53 & $0.0313 * *$ & 2.312 & 2.641 & 2.666 & 789 & $0.0447 * * *$ & 13.385 & 13.112 & 9.343 & $-0.0133 * * *$ & -5.909 \\
\hline $\operatorname{MCAAR}(-2,+2)$ & 53 & $0.0512 * * *$ & 2.567 & 2.678 & 2.777 & 789 & $0.0588 * * *$ & 13.114 & 12.456 & 8.658 & -0.0076 & -1.060 \\
\hline $\operatorname{MCAAR}(-3,+3)$ & 53 & $0.0653 * * *$ & 2.778 & 2.677 & 2.658 & 789 & $0.0697 * * *$ & 12.227 & 12.114 & 8.056 & -0.0044 & -0.690 \\
\hline $\operatorname{MCAAR}(-5,+5)$ & 53 & $0.0700 * *$ & 2.334 & 2.556 & 2.041 & 789 & $0.0833 * * *$ & 11.116 & 11.256 & 6.219 & -0.0132 & -0.172 \\
\hline
\end{tabular}

$* * *, * *$, and $*$ indicate statistical significance at the $1 \%, 5 \%$ and $10 \%$ levels respectively using t-statistics. 